\title{
PENGENDALI LAMPU MONITORING RUMAH DENGAN SHORT MESSAGE SERVICE (SMS) BERBASIS ARDUINO UNO
}

\author{
Mohammad Taufan Asri Zaen ${ }^{1}$, Asep Yunandy ${ }^{2}$ \\ ${ }^{1}$ Sistem Informasi, STMIK Lombok \\ ${ }^{2}$ Teknik Informatika, STMIK Lombok \\ 10panzain@gmail.com, 2asepyunandi@yahoo.co.id
}

\begin{abstract}
The increasing activity of someone outside the home causes difficulties in controlling the lamps and monitoring the condition of the house from a distance, therefore it is necessary to control the lamps remotely. This research designed and built a lamps handling by short message service (SMS) based on arduino uno.

Lamps handling by sms is a tool which act as the lamp and alarm switches at house, whenever without time limits as far as the GSM signal is still can be reached. Handling tool from distance by mobile sms act as an order producer, arduino uno as a microcontroller, sensor peer as a movement detector, gsm modul sim $900 \mathrm{~A}$ as an information sender and acceptor and relay as a switcher of lamps or the alarms.

The test results of this tool show that this too can be used based on the order which is given from distance to control the lamps and the alarms. Another function of this tool is to monitor the lamps condition by "cek" function to know in which lamp is on or off mode. It also can switch on an alarm and send some sms to the owner's contact number when its sensor detected any object movements.
\end{abstract}

Keywords: Arduino Uno, SIM900A, SMS(Short Message Service), PIR(Passive Infra-Red)

\begin{abstract}
Abstrak
Aktifitas seseorang diluar rumah yang semakin meningkat menyebabkan terjadinya kesulitan dalam mengontrol lampu penerangan dan memonitoring keadaan rumah dari jarak jauh, oleh karena itu diperlukan pengendali lampu dari jarak jauh. Penelitian ini merancang dan membangun alat pengendali lampu jarak jauh dengan short message service (SMS) berbasis arduino uno.

Pengendalian lampu mengunakan sms ini merupakan alat yang berfungsi untuk menghidupkan dan mematikan lampu dan alarm yang ada dirumah kapan saja dan tidak terbatas oleh waktu dan tempat selama masih terjangkau sinyal operator gsm. Pengendali jarak jauh mengunakan short message service (SMS) dari handphone sebagai pemberi perintah, arduino uno sebagai mikrokontroler, sensor pir sebagai pendeteksi gerakan, modul gsm sim900a sebagai menerima dan mengirim informasi, relay sebagai saklar untuk mengidupkan dan mematikan lampu dan alarm.

Hasil pengujian dari alat ini menunjukan bahwa alat ini dapat berfungsi sesuai dengan perintah yang diberikan untuk mengendalikan lampu dan alarm dari jarak jauh, dapat memonitoring keadaan lampu dengan perintah "cek" untuk mengetahui mana lampu yang hidup atau mati dan juga dapat memonitoring keadaan rumah mengunakan sensor pir yang berfungsi untuk menghidupkan alarm dan mengirimkan sms ke nomor pemilik ketika sensor mendeteksi pergerakan objek.
\end{abstract}

Kata kunci:: Arduino Uno, SIM900A, SMS(Short Message Service), PIR(Passive Infra-Red)

ISSN. 2620-6900 (Online) 2620-6897 (Cetak) 


\section{Pendahuluan}

Seiring dengan perkembangan jaman, aktivitas manusia semakin meningkat dan terkadang menuntut manusia harus meninggalkan rumah. Aktivitas seseorang diluar rumah dalam waktu yang lama akan menyebabkan seseorang mengalami kesulitan dalam memonitoring keadaan rumah dan kesulitan berinteraksi dengan peralatan listrik yang ada di rumah, salah satunya adalah lampu penerangan.

Saat rumah dalam keadaan kosong tak berpenghuni akibat pemilik rumah ada aktivitas diluar rumah, maka tidak ada yang menyalakan lampu saat malam hari yang meyebapkan rumah dalam keadaan gelap dan tidak ada yang mematikan lampu saat siang hari. Jika lampu dinyalakan terlebih dahulu sebelum seseorang berpergian dalam waktu lebih dari 24 jam, akibatnya selain pemborosan biaya listrik, juga memiliki dampak negatif seperti lampu mudah rusak atau mati karena menyala terus menerus, selain itu pemilik rumah juga khawatir terhadap keamanan rumahnya karena tidak dapat memonitoring keadaan rumah.

Melihat kondisi tersebut, maka penelitian berupaya untuk membuat alat penedali lampu dan monitoring rumah jarak jauh yang berfungsi untuk menghidupkan dan mematikan lampu yang ada dirumah dan memberikan informasi tentang keadaan rumah kapan saja dan tidak terbatas oleh waktu dan tempat selama masih terjangkau sinyal operator gsm. Alat pengendali jarak jauh menggunakan sms (short message service) dari handphone, arduino uno sebagai mikrokontroler, sensor pir sebagai pendeteksi gerakan, modul sim900a sebagai menerima dan mengirim informasi.

\section{Tinjauan Pustaka}

Andreas, dkk (2015), dalam penelitianya tentang "Rancang Bangun Kontrol dan Pemonitoran Lampu Rumah dengan Smartphone Android berbasis SMS Gateway dan mikrokontroler Atmega16", pembuatan alat ini mengunakan mikrokontroler atmega16 sebagai modul pengendali utamanya, aplikasi android sebagai media interface kendali dan model GSM Wavecom sebagai penghubung antara mikro kontroler dan handphone android untuk memberikan dan mengirim informasi informasi.

Sadewa, $d k k$ (2015), dalam penelitiannya "Implementasi Mikrokontroler pada Kontrol Peralatan Listrik dan Monitoring Rumah Berbasis Website" permasalahan yang terjadi adalah pengontrolan listrik secara manual mengunakan saklar yang harus dioperasikan dengan bantuan manusia dimana pendendalian tersebut terbentur oleh jarak. Tujuan dari penelitian tersebut yaitu sebagai salah satu solusi agar suatu perangkat dapat di control secara maksimal dan cakupan kontrolnya semakin luas.penelitian tersebut menghasilkan sistem yang dapat mengontrol listrik dan monitoring rumah yang mendukung multi pengguna.

Rezky, dkk (2016), dalam penelitianya tentang "Rancang Bangun HSS(Home Security Sistem) Berbasis sms Gateway mengunakan Arduino Uno" Tujuan pembuatan alat ini adalah untuk mencegah terjadinya pencurian yang terjadi di dalam rumah sehingga pemilik rumah dapat mengetahui jika sewaktu waktu terjadi pembobolan rumah. Alat ini memanfaatkan teknologi arduino uno, GSM Shiled, keypad, Relay, Smartphone android,gsm shiled berfungsi untuk mengirimkan informasi apabila terjadi pembobolan rumah dalam bentuk sms.

Bahri (2017), dalam penelitiannya tentang sistem kontrol penerangan mengunakan arduino uno pada universitas ichsan gorontalo. Penelitian tersebut bertujuan untuk membuat sebuah sistem control yang secara otomatis dapat bertindak sebagai pengatur penggunaan penerangan pada kampus tersebut. Aplikasi yang di buat mengunakan bahasa pemrogramandelphi dan untuk mempogram papan mikrokontroler mengunakan bahasa pemrograman C-arduino serta microsoft office acces sebagai database.

Fauzi, $d k k$ (2018), dalam penelitianya mengenai "Pemanfaatan Modul GSM (sim 900) berbasis arduino-uno sebagai sistem alarm dan pengunci pintu otomatis jarak jauh" permasalahan yang terjadi adalah karna kekhwatiran ankan tingkat kriminal dan jenis kejahatan juga semakin bertambah di dukung dengan keahlian pencuri masing-masing.tujuan dari penelitian tersebut yaitu membagun rumah pintar yang mampu melakukan dua hal yakni mengunci pintu dan menyalakan alarm. Sehingga keamanan rumah akan tetap dapat dikendalikan meskipun dari jarak yang jauh.

Perbedaan dengan penelitian sebelumnya, penelitian ini akan merancang dan membagun suatu alat pengendali lampu mengunakan perintah sms dari handphone arduino uno sebagai mikrokontroler,sensor pir sebagai pendeteksi gerakan, modul gsm sim900a sebagai penerima dan mengirim informasi lampu tersebut hidup atau mati dan juga mengirim informasi ketika sensor pir mendeteksi pergerakan ke nomor yang telah di tentukan. 


\section{Metodologi}

Perancangan alat dibuat untuk membantu dan mempermudah dalam mengerjakan alat yang akan dibuat. Perancangan alat dimulai dari pembuatan blok diagram dimana setiap blok tersebut mempunyai fungsi tersendiri yang saling terkait sehingga membentuk sistem dari alat yang akan dibuat.

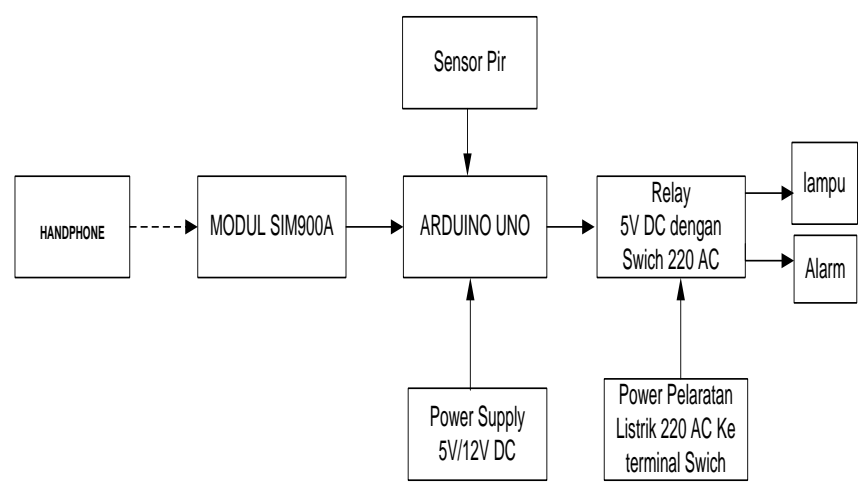

Gambar 3.1. Blok diagram sistem kendali Lampu dan Alarm

Fungsi masing-Masing blok diagram yang ditunjukkan oleh gambar $3.1 \mathrm{di}$ atas adalah sebagai berikut:

1. Arduino uno berfungsi sebagai pusat pengolah data

2. Sim900 Berfungsi sebagai Penghubung arduino uno dan Handphone

3. Handphone berfugsi sebagai Pemberi perintah atau masukan

4. Tegangan DC5V dan AC 220V Sebagai Pemberi sumber Tegangan pada Arduino dan Lampu

5. Relay berfungsi sebagai kontak pengatur arus listrik NO/NC

6. Lampu dan alarm berfungsi sebagai media hasil Output

\subsection{Flowchat}

Alur kerja alat ditunjukkan pada flowchart pada gambar 3.2 di bawah ini adalah sebagai berikut:

1. Ketika alat pertamakali di hidupkan maka arduino akan mengirim sms ke nomor pemilik berupa status ready dan kode-kode yang di gunakan pengendali lampu.

2. Pemilik megirim sms kode perintah ke sim900a

3. Jika kode sms sesuai maka jalankan perintah ke arduino

4. Arduino menjalankan perintah dan mengirim sms balasan.

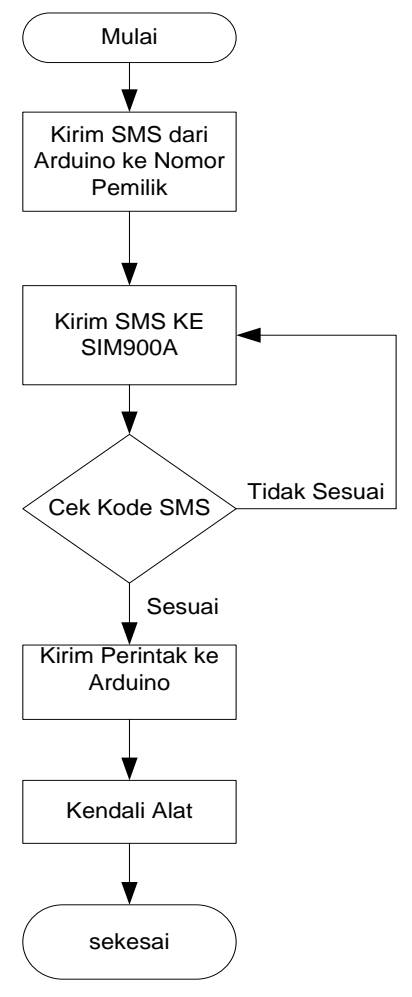

Gambar 3.2. Flowchat Kerja Alat

\subsection{Skematik}

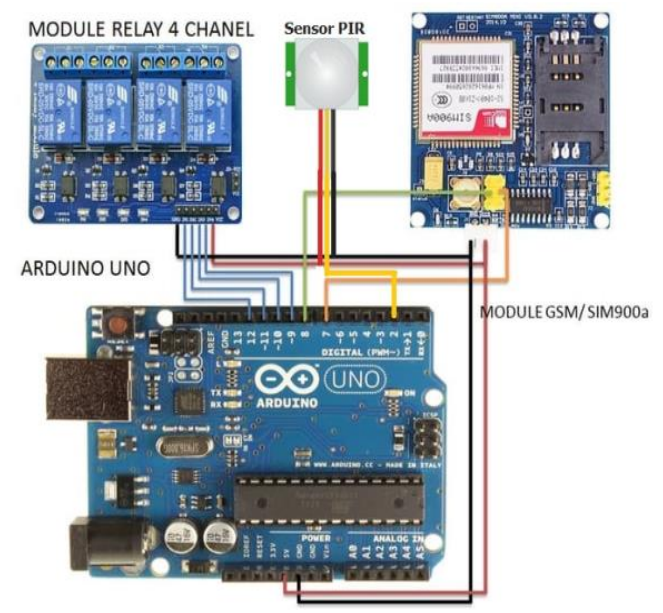

Gambar 3.3. Skematik Alat

Sesuai dengan gambar 3.3, alat ini menggunakan 4 (empat) komponen yaitu utama:

1. Arduino uno

Sebuah keping yang secara fungsional bertindak seperti sebuah komputer. Piranti ini dapat dimanfaatkan untuk mewujudkan rangkaian elektronik dari yang sederhana hingga yang kompleks

2. SIM 900A berfungsi sebagai penghubung arduino dengan handphone.

3. Relay berfungsi sebagai kontak pengatur arus listrik NO/NC

4. Sensor Pir untuk menghidupkan alarm. 
Tabel 3.1 Tabel Konfigurasi Pin

\begin{tabular}{|c|l|l|}
\hline Modul & $\begin{array}{c}\text { Pin yang } \\
\text { digunakan }\end{array}$ & \multicolumn{1}{c|}{ Keterangan } \\
\hline \multirow{3}{*}{ SIM900 } & TX & TX ke Pin 7 Arduino \\
\cline { 2 - 3 } & RX & RX ke Pin 8 Arduino \\
\cline { 2 - 3 } & GND & $\begin{array}{l}\text { GND ke pin GND } \\
\text { Arduino }\end{array}$ \\
\cline { 2 - 3 } & VCC & VCC ke pin 5V arduino \\
\hline Relay & VCC & VCC ke pin 5V \\
\hline \multirow{3}{*}{} & GND & $\begin{array}{l}\text { GND ke Pin GND } \\
\text { arduino }\end{array}$ \\
\cline { 2 - 3 } & IN1 & IN1 ke pin 9 arduino \\
\cline { 2 - 3 } & IN2 & IN2 ke pin 10 arduino \\
\cline { 2 - 3 } IN3 & IN3 ke pin 11 arduino \\
\hline PIR & VCC & VCC ke pin 5V \\
\hline \multirow{2}{*}{} & GNC & $\begin{array}{l}\text { GND KE Pin GND } \\
\text { arduino }\end{array}$ \\
\cline { 2 - 3 } & OUT & OUT ke Pin 2 Arduino \\
\hline
\end{tabular}

\section{Hasil Dan Pembahasan}

\subsection{Implementasi Sistem}

Tahap implementasi merupakan tahap kelanjutan dari kegiatan perancangan sistem. Wujud dari hasil implementasi ini nantinya adalah sebuah sistem yang siap untuk diuji dan digunakan.

\subsection{Implementasi Perangkat Keras}

Spesifikasi perangkat keras(hardware) yang digunakan untuk mengimplemetasikan alat Pengendali lampu denga sms dapat dilihat pada tabel 4.1.

Tabel 4.1 Spesifikasi Alat

\begin{tabular}{|c|c|c|c|}
\hline No & Alat & \multicolumn{2}{|c|}{ Spesifikasi } \\
\hline \multirow{17}{*}{1} & \multirow{17}{*}{$\begin{array}{c}\text { Arduino } \\
\text { Uno }\end{array}$} & Microcontroller & : ATmega328P \\
\hline & & Operating Voltage & $: 5 \mathrm{~V}$ \\
\hline & & Input Voltage & $: 7-12 \mathrm{~V}$ \\
\hline & & (recommended) & \\
\hline & & Input Voltage & $6-20 \mathrm{~V}$ \\
\hline & & Digital I/O Pins & 14 (6 PWM \\
\hline & & Pin Analog input & Output) \\
\hline & & Arus DC per I/O & $: 6$ \\
\hline & & Arus DC untuk & $20 \mathrm{~mA}$ \\
\hline & & 3.3V Pin & \\
\hline & & Flash Memory & $50 \mathrm{~mA}$ \\
\hline & & SRAM & : $32 \mathrm{~KB}$ \\
\hline & & & (ATmega328P) \\
\hline & & EEPROM & $: 0.5 \mathrm{~KB}$ untuk \\
\hline & & & $2 \mathrm{~KB}$ \\
\hline & & & (ATmega328P) \\
\hline & & Clock Speed & $: 16 \mathrm{MHz}$ \\
\hline
\end{tabular}

\begin{tabular}{|c|c|c|}
\hline No & Alat & Spesifikasi \\
\hline 2 & $\begin{array}{l}\text { Modul } \\
\text { GSM } \\
\text { SIM900A }\end{array}$ & $\begin{array}{l}\text { Dual-Band 900/ } 1800 \mathrm{MHz} \\
\text { GPRS multi-slot class 10/8 } \\
\text { GPRS mobile station class B } \\
\text { Compliant to GSM phase 2/2+ } \\
\text { Class } 4 \text { (2 W @ } 900 \mathrm{MHz}) \\
\text { Class } 1 \text { (1 W @ } 1800 \mathrm{MHz}) \\
\text { Control via AT commands (GSM } \\
07.07,07.05 \text { and SIMCOM enhanced } \\
\text { AT Commands) } \\
\text { SIM application toolkit } \\
\text { Supply voltage range: } 3.1-4.8 \mathrm{~V} \text { (Supply } \\
\text { Vin ke shield = 9 - 15volt) } \\
\text { Low power consumption: } 1.5 \mathrm{~mA} \text { (sleep } \\
\text { mode) } \\
\text { Operation temperature: }-40 \mathrm{C} \text { to }+85 \mathrm{C}\end{array}$ \\
\hline 3 & $\begin{array}{l}\text { Modul } \\
\text { Relay }\end{array}$ & $\begin{array}{l}\text { Input relay } 5 \mathrm{~V} \text { DC } \\
\text { Maksimum load } 250 \mathrm{VAC} / 10 \mathrm{~A} \\
\text { 30VDC/10A } \\
\text { Output keluaran } 4 \text { channel maksimal 10A } \\
\text { Output memiliki } 3 \text { pin terminal block } \\
\text { yang ditandai dengan NO, COM dan NC. } \\
\text { NO (Normally Open) = Tidak ada arus } \\
\text { yang dialirkan (OFF), Jika ada signal } \\
\text { High / Low dari microcontroller maka } \\
\text { ON } \\
\text { COM (Common) = Sumber tegangan } \\
\text { yang akan dihubungkan (Bisa arus AC } \\
\text { maupun DC 10A max) } \\
\text { NC (Normally Close) = Arus dialirkan } \\
\text { (ON), Jika ada signal High / Low dari } \\
\text { microcontroller maka OFF }\end{array}$ \\
\hline 4 & $\begin{array}{l}\text { Sensor } \\
\text { PIR }\end{array}$ & $\begin{array}{l}\text { Voltage: } 5 \mathrm{~V}-20 \mathrm{~V} \\
\text { Power Consumption }: 65 \mathrm{~mA} \\
\text { TTL Output }: 3.3 \mathrm{~V} \\
\text { Delay time }: \text { adjustable }(.3->5 \mathrm{~min}) \\
\text { Lock time }: 0.2 \text { sec } \\
\text { Sensing range :less than } 120 \\
\text { degree, within } 7 \text { meter } \\
\text { Temperature: }-15 \sim+70 \\
\text { Dimension: } 32 * 24 \mathrm{~mm} \text {, distance between } \\
\text { screw } 28 \mathrm{~mm}, \mathrm{M} 2, \text { Lens dimension in } \\
\text { diameter }: 23 \mathrm{~mm}\end{array}$ \\
\hline 5 & $\begin{array}{l}\text { Balon } \\
\text { Lampu }\end{array}$ & $\begin{array}{l}\text { Daya } 5 \text { Watt } \\
\text { Kaca Lampu Bening } \\
\text { Cahaya Warm White } \\
\text { Fitting E27 }\end{array}$ \\
\hline 6 & $\begin{array}{l}\text { Flash } \\
\text { Buzzer }\end{array}$ & $\begin{array}{l}\text { Tipe:AD16-22SM } \\
\text { Tegangan kerja: 220v AC } \\
\text { Output: Flashing LED (merah) dan } \\
\text { Suara } \\
\text { Instalasi: lobang diameter } 22 \mathrm{~mm}\end{array}$ \\
\hline
\end{tabular}




\subsubsection{Rangkaian Alat}

Alat yang di rangkai terlihat pada gambar 4.1

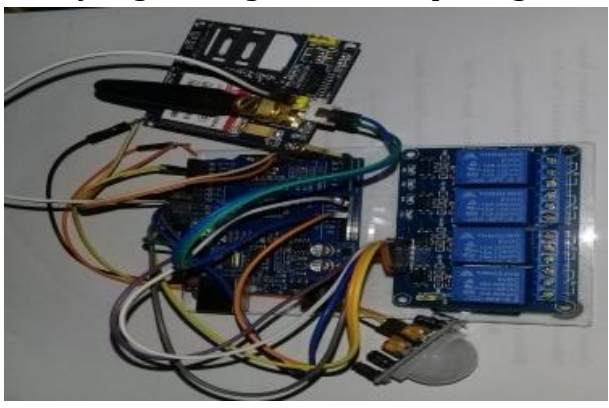

Gambar 4.1. Rangkaian Alat

\subsubsection{Rangkaian Pengontrol Utama}

Rangkaian pengontrol

utama menggunakan Arduinouno R3 yang didalamnya terdapat mikrokontroler ATMega328. Rangkaian pengontrol utama berfungsi sebagai penerima data masukan dari pendeteksi sinyal masukan dan mengelolah data-data yang masuk, menentukan operasi pengendalian input output dan kemudian mengirimkan sinyal-sinyal tersebut ke setiap pin-pin keluaran.

\subsubsection{Rangkaian SIM 900A}

GSM Shield atau GPRS (General Packet Radio Service) Shield yang digunakan adalah sim900a. Beroperasi pada frekuensi GSM/GPRS $850 / 900 / 1800 / 1900 \mathrm{MHz}$ digunakan untuk mengirim sms ke pengguna bahwa alat siap diberi perintah, dan menerima sms dari pengguna untuk di proses dan mengeksekusi relay pada peralatan dengan mengetikkan kode sesuai dengan kode yang dikenal oleh Arduino.

\subsubsection{Rangkaian Relay Kontaktor}

Rangkaian relay kontaktor yang digunakan merupakan Relay Shield yang juga kompatibel dengan Arduino Uno R3, tegangan kerjanya +5VDC sampai +12VDC, modul relay ini memiliki 4 buah kontaktor yang lilitan atau kumparan nya bekerja pada tegangan +5VDC, sedangkan kontaknya maksimal bisa dilalui 250VAC pada tegangan AC dan 30VDC pada tegangan searah atau DC, dengan Arus maksimal yang dapat melalui kontak sebesar 10A

\subsubsection{Hasil Akhir Rangkaian Hardware}

Setelah semua alat dirangkai dari modul gsm sim900a,mikrokontroler arduino uno, modul relay, pengkabelan dan output berupa lampu dan buzzer maka alat tersebut seperti gambar 4.2.

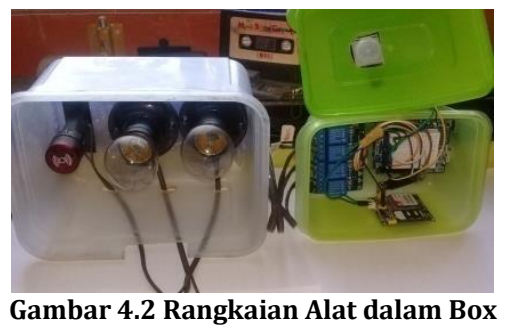

4.3. Implementasi Perangkat Lunak (Software) Implementasi perangkat lunak yang digunakan untuk pemrograman pada mikrokontoler arduino uno mengunakan bahasa C. Penulis Mengunakan program IDE(Integrated Development Enviroment) Arduino versi 1.8.5. Program ini dapat mengidentifikasi validasi baris naskah program, melalui proses compile atau menerjemahkan baris program kedalam bahasa biner, dan mampu menulis hasil compile kedalam mikrokontroler. File project dari program arduino memiliki extensi file ino.

Setelah semuanya siap,penulis melakukan pengetikan dan penyuntingan naskah program sesuai dengan flowchat algoritma pemrograman yang telah di buat. Setelah selesai menuliskan naskah program,penulis melakukan proses upload untuk memasukkan program kedalam mikrokontroler arduino uno.

Dalam pembuatan program tersebut penulis juga mengunakan library dari modul gsm shield untuk mempermudah dalam penulisan script program yang dibuat.

Proses memasukkan program kedalam mikrokotroler arduino uno yang di maksud, di tunjukan oleh gambar 4.3.

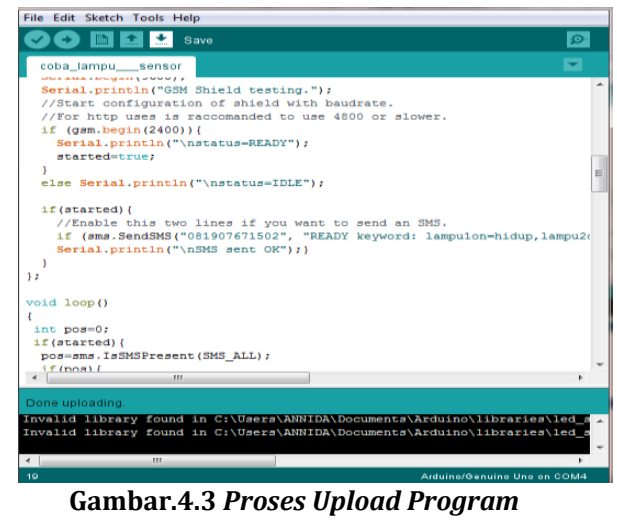

\subsection{Pengujian}

Pengujian dilakukan untuk mengetahui apakah fungsi-fungsi dari alat dan aplikasi yang telah di rancang dapat bekerja degan baik atau tidak. Pengujian alat juga berguna untuk mengetahui tingkat kinerja dan fungsi tersebut. Pengujian yang di lakukan meliputi pengujian Hardware dan pengujian aplikasi. 


\subsubsection{Pengujian Arduino Uno}

Pengujian alat dilakukan untuk mengetahui apakah alat yang direncanakan bekerja dengan baik atau tidak. Pengujian sistem yang di lakukan oleh penulis adalah modul mikrokontroler arduino uno dan modul SIM900A. untuk komunikasi modul mikrokontroler arduino uno dapat di lakukan dengan satu unit komputer atau laptop.

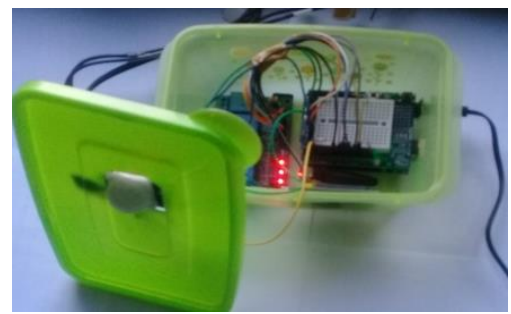

Gambar 4.4 Pengujian Arduino Uno

\subsubsection{Pengujian Modul GSM SIM 900A}

Pengujian Komunikasi serial Fungsi setup untuk menguji komunikasi serial antara arduino denga modul gsm sim900a adalah sebagai berikut:

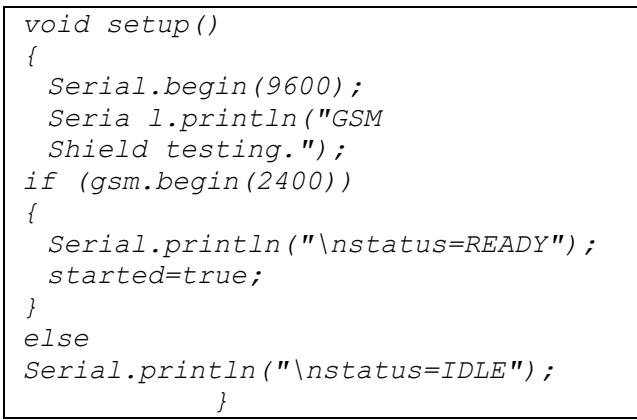

Jika pada serial monitor menunjukkan setatus ready maka komunikasi serial antara arduino dengan modul gsm sim900a sudah dapat di lakukan. Namun jika serial monitor menunjukkan status idle, maka secara otomatis software arduino akan menyesuaikan baut rate yang dapat digunakan untuk melakukan komunikasi serial pengujian untuk menerima dan membaca pesan singkat.

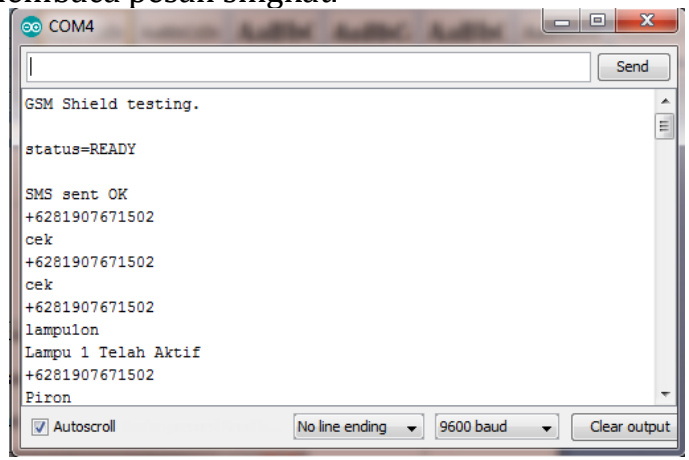

Gambar 4.5 Komunikasi Serial Arduino

\subsubsection{Pengujian dengan perintah SMS}

Tabel 4.3. Kode-kode SMS

\begin{tabular}{|c|l|l|l|}
\hline No & $\begin{array}{l}\text { Nomor Handphone } \\
\text { \& Kode SMS }\end{array}$ & $\begin{array}{c}\text { Alat yang } \\
\text { bekerja }\end{array}$ & Keterangan \\
\hline 1 & $\begin{array}{l}087712480918 \\
\text { lampu1on }\end{array}$ & $\begin{array}{l}\text { Saklar Relay } \\
1 \text { terhubung }\end{array}$ & $\begin{array}{l}\text { Lampu 1 } \\
\text { Menyala }\end{array}$ \\
\hline 2 & $\begin{array}{l}087712480918 \\
\text { lampu2on }\end{array}$ & $\begin{array}{l}\text { Saklar Relay 2 } \\
\text { terhubung }\end{array}$ & $\begin{array}{l}\text { Lampu 2 } \\
\text { Menyala }\end{array}$ \\
\hline 3 & $\begin{array}{l}087712480918 \\
\text { semuaon }\end{array}$ & $\begin{array}{l}\text { Saklar Relay } \\
1,2 \text { terhubung }\end{array}$ & $\begin{array}{l}\text { Lampu 1,2 } \\
\text { Menyala }\end{array}$ \\
\hline 4 & $\begin{array}{l}087712480918 \\
\text { lampu1off }\end{array}$ & $\begin{array}{l}\text { Saklar Relay } \\
1 \text { terputus }\end{array}$ & $\begin{array}{l}\text { Lampu 1 } \\
\text { Padam }\end{array}$ \\
\hline 5 & $\begin{array}{l}087712480918 \\
\text { lampu2off }\end{array}$ & $\begin{array}{l}\text { Saklar Relay } \\
\text { 2 terputus }\end{array}$ & $\begin{array}{l}\text { Lampu 2 } \\
\text { Padam }\end{array}$ \\
\hline 6 & $\begin{array}{l}087712480918 \\
\text { semuaoff }\end{array}$ & $\begin{array}{l}\text { Saklar Relay } \\
1,2 \text { terputus }\end{array}$ & $\begin{array}{l}\text { Lampu 1,2 } \\
\text { padam }\end{array}$ \\
\hline 5 & $\begin{array}{l}087712480918 \\
\text { piron }\end{array}$ & $\begin{array}{l}\text { Saklar relay 3 } \\
\text { terhubung }\end{array}$ & $\begin{array}{l}\text { Sensor pir } \\
\text { diaktifkan }\end{array}$ \\
\hline 6 & $\begin{array}{l}087712480918 \\
\text { piroff }\end{array}$ & $\begin{array}{l}\text { Saklar relay 3 } \\
\text { terputus }\end{array}$ & $\begin{array}{l}\text { Sensor pir di } \\
\text { nonaktifkan }\end{array}$ \\
\hline 7 & $\begin{array}{l}087712480918 \\
\text { Cek }\end{array}$ & $\begin{array}{l}\text { Untuk mengetahui lampu yang } \\
\text { menyala/tidak }\end{array}$ \\
\hline
\end{tabular}

Setelah rangkaian diberi tegangan dan dapat dioperasikan dengan menekan tombol reset pada arduino, gsm sim900a akan mengirimkan sms kepada nomor yang telah ditunjuk, dengan isi sms menyatakan bahwa alat siap menerima perintah.

Selanjutnya nomor tersebut dapat mengirim pesan ke nomor yang telah di masukkan, kita dapat membalas pesan tersebut dengan kode sms yang telah ditentukan untuk memberi tegangan ke saklar sehingga saklar akan bekerja sesuai instruksi sms.

\subsubsection{Hasil Pengujian dengan kode SMS} Tabel 4.4.Hasil Pengujian Menggunakan SMS

\begin{tabular}{|c|l|l|l|l|l|l|}
\hline No & $\begin{array}{c}\text { Nomor } \\
\text { Handphone \& } \\
\text { Isi SMS }\end{array}$ & $\begin{array}{c}\text { Keterangan } \\
\text { SMS }\end{array}$ & L1 & L2 & Pir & $\begin{array}{c}\text { Has } \\
\text { il }\end{array}$ \\
\hline 1 & $\begin{array}{l}\text { 087712480918 } \\
\text { lampu1on }\end{array}$ & $\begin{array}{l}\text { Lampu1 telah } \\
\text { aktif }\end{array}$ & on & off & off & ok \\
\hline 2 & $\begin{array}{l}087712480918 \\
\text { lampu2on }\end{array}$ & $\begin{array}{l}\text { Lampu 2 telah } \\
\text { aktif }\end{array}$ & on & on & off & ok \\
\hline 3 & $\begin{array}{l}087712480918 \\
\text { semuaon }\end{array}$ & $\begin{array}{l}\text { Semua lampu } \\
\text { telah aktif }\end{array}$ & off & on & off & ok \\
\hline 4 & $\begin{array}{l}087712480918 \\
\text { lampu1off }\end{array}$ & $\begin{array}{l}\text { Lampu 1 telah } \\
\text { di nonaktifkan }\end{array}$ & off & off & off & ok \\
\hline 5 & $\begin{array}{l}087712480918 \\
\text { lampu2off }\end{array}$ & $\begin{array}{l}\text { Lampu 2 telah } \\
\text { di nonaktifkan }\end{array}$ & on & on & off & ok \\
\hline 6 & $\begin{array}{l}087712480918 \\
\text { semuaoff }\end{array}$ & $\begin{array}{l}\text { Semua Lampu } \\
\text { telah di } \\
\text { nonaktifkan }\end{array}$ & off & off & off & ok \\
\hline 7 & $\begin{array}{l}087712480918 \\
\text { piron }\end{array}$ & $\begin{array}{l}\text { Sensor pir } \\
\text { telah di } \\
\text { aktifkan }\end{array}$ & $\begin{array}{l}\text { Sensor pir } \\
\text { telah di } \\
\text { nonaktifkan }\end{array}$ & - & - & off \\
\hline
\end{tabular}

Tabel 4.5 Tabel hasil pengukuran waktu sms untuk eksekusi sistem 


\begin{tabular}{|c|c|c|c|}
\hline $\begin{array}{c}\text { Percobaan } \\
\text { SMS }\end{array}$ & $\begin{array}{c}\text { Waktu kirim } \\
\text { SMS sampai } \\
\text { Lampu } \\
\text { menyala }\end{array}$ & $\begin{array}{c}\text { Waktu kirim } \\
\text { sms sampai } \\
\text { menerima } \\
\text { sms balasan }\end{array}$ & $\begin{array}{c}\text { Waktu kirim } \\
\text { sms sampai } \\
\text { lampu padam }\end{array}$ \\
\hline 1 & 5.70 & 13.60 & 5.03 \\
\hline 2 & 5.41 & 13.89 & 4.91 \\
\hline 3 & 5.53 & 17.92 & 4.40 \\
\hline 4 & 7.84 & 15.67 & 5.04 \\
\hline 5 & 5.62 & 13.87 & 5.31 \\
\hline 6 & 4.70 & 16.01 & 5.17 \\
\hline 7 & 5.11 & 13.95 & 6.61 \\
\hline 8 & 5.72 & 14.32 & 5.04 \\
\hline 9 & 4.00 & 13.24 & 5.72 \\
\hline 10 & 5.43 & 12.53 & 3.99 \\
\hline Jumlah & 55.06 & 145 & 51.22 \\
\hline Rata -Rata & 5.5 & 14.5 & 5.12 \\
\hline
\end{tabular}

*Waktu Kirim SMS (dalam detik)

\subsubsection{Pengujian Sensor Passive Infrared (PIR)}

Pengujian pada sensor ini bertujuan untuk mengetahui sensitifitas sensor dalam mendeteksi objek. Pendeteksian objek pada jarak dekat dan jarak jauh bertujuan untuk mengetahui sensor berfungsi atau tidak dalam mendeteksi objek dan juga mengetahui apakah sensor dapat bekerja untuk menghidupkan alarm dan megirimkan sms ke nomor pemilik apabila mendeteksi objek yang terdapat di depan sensor. Sensor ini akan di letakkan di luar ruangan. Objek yang akan di deteksi dalam pengujian yaitu manusia dan tumbuhan, dimana dilakukan 6 kali percobaan dari tiap objek pada jarak 1 hingga 6 meter dan berikut merupakan hasil pengujian sensor PIR terhadap objek.

Tabel 4.6. Hasil Pengujian sensor PIR terhadap Objek

\begin{tabular}{|c|c|l|}
\hline Objek & $\begin{array}{c}\text { Jarak } \\
\text { (Meter) }\end{array}$ & \multicolumn{1}{c|}{ Respon } \\
\hline \multirow{4}{*}{ Manusia } & 1 & Alarm aktif dan mengirimkan sms \\
\cline { 2 - 3 } & 2 & Alarm aktif dan mengirimkan sms \\
\cline { 2 - 3 } & 3 & Alarm aktif dan mengirimkan sms \\
\cline { 2 - 3 } & 4 & Alarm aktif dan mengirimkan sms \\
\cline { 2 - 3 } & 5 & Alarm aktif dan mengirimkan sms \\
\hline \multirow{4}{*}{ Tumbuhan } & 6 & Alarm tifak aktif \\
\cline { 2 - 3 } & 1 & Alarm tifak aktif \\
\cline { 2 - 3 } & 2 & Alarm tifak aktif \\
\cline { 2 - 3 } & 3 & Alarm tifak aktif \\
\cline { 2 - 3 } & 4 & Alarm tifak aktif \\
\cline { 2 - 3 } & 6 & Alarm tifak aktif \\
\hline
\end{tabular}

\subsubsection{Pengujian Lab}

Pengujian lab di kakukan ketika penguna berada di depan alat tersebut. Berikut gambar pengujian yang di lakukan.

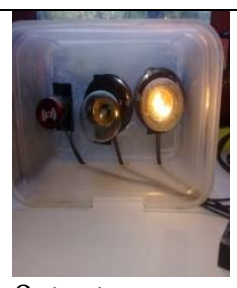

Output

lampu1on

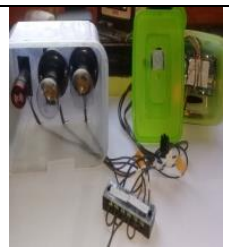

Output Semuaoff

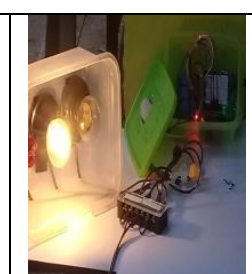

Output lampu2on

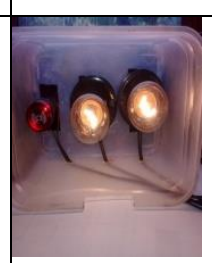

Output semuaon

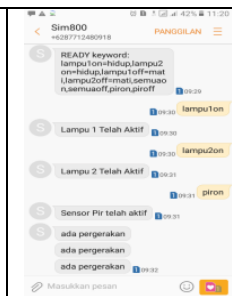

Output balasan sms

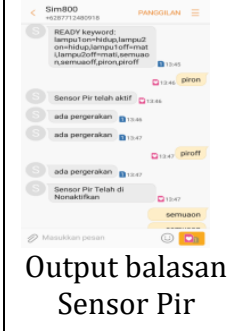

Gambar 4.6 Hasil Pengujian Lab.

\subsubsection{Pengujian Lapangan}

Pengujian lapangan di lakukan untuk mengetahui apakah alat dapat bekerja atau di operasikan dari jarak jauh.

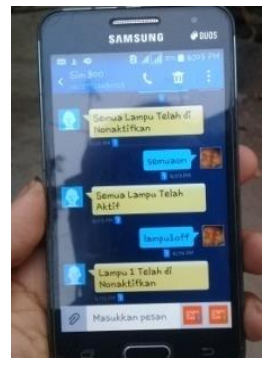

Gambar 4.6 Hasil Balasan Perintah sms

\section{PENUTUP}

\subsection{Kesimpulan}

Kesimpulan yang bisa diambil dalam perancangan alat pengendali dan monitoring rumah dengan sms berbasis arduino uno adalah sebagai berikut:

1. Peralatan ini telah diuji dan dapat digunakan untuk mengendalikan lampu dan sensor pir dari jarak jauh sesuai dengan perintah yang dikirimkan.

2. Peralatan ini dapat membantu pemakai untuk mengendalikan dan memonitoring kondisi lampu dan keadaan rumah dari jarak jauh menggunakan handphone yang dimiliki.

3. Adanya SMS balasan yang menyatakan bahwa lampu dan sensor telah diaktifkan 
atau di nonaktifkan membuktikan umpan balik alat bekerja.

4. Mikrokontroler Arduino dapat menjadi pusat pengontrol perangkat lain dengan penambahan gsm sim900a, arduino dapat menggunakan isi dari pesan singkat yang diterima oleh gsm sim900a sebagai pemicu aksi untuk mengontrol perangkat lain sekaligus mengirim pesan singkat dari gsm sim900a ke handphone.

\subsection{Saran}

Dalam pembuatan alat pengendali lampu dan monitoring rumah dengan sms berbasis mikrokontroler arduino uno masih adanya yang harus di perbaiki, yaitu:

1. Belum adanya informasi ketika penguna mengirim sms dengan format yang salah.

2. Untuk menambah tingkat keamanan dalam memonitoring rumahbisa di tambah dengan sensor lain misalkan mangnetic swich.

\section{DAFTAR PUSTAKA}

[1] Andreas F.triyanto D.2015.Rancang Bangun Kontrol Dan Pemonitoringan Lampu Rumah Dengan Smartphone Android Berbasis Sms Gateway Dan Mikrokontroler. Pontianak: Jurnal koding sistem computer utama,vol.03.no: 33-43.

[2] Bahrin.2017. Sistem Control Penerangan Mengunakan Arduino Uno Pada Universitas Ichsan Gorontalo. Gorontalo: ilkom jurnal ilmiah .vol 9,no 3

[3] Budiharto, Widodo. 2004. Interfacing Komputer dan Mikrokontroler. Jakarta : PT Elek Media Komputindo Kelompok Gramedia .

[4] Cristison P.R. Muh.yamin Muchlis N.F. 2016.Rancang Bangun HSS(home Scurity Sistem) berbasis SMS Gateway Mengunakan Arduino Uno.Kendari : semantic.vol 2, No.135-144

[5] Febriansyah, Dwi dan Haris Kuswara . 2014.Alat kendali lampu rumah menggunakan Bloethoot berbasis android. PalComTech, Palembang
[6] Hamid, Marsud, dkk. 2008. Kontrol Ac Jarak Jauh Dengan Menggunakan Handphone. Jurnal Media Elektrik. Volume 3, Nomor 1.

[7] Meta Amalia Dewi, Henderi. 2011. "Perancangan Strategik SI/TI Pemerintah Kota Tangerang dalam Mewujudkan EGovernment". Journal CCIT Vol.5 No.3 September 2011 ISSN: 1978 - 8282 STMIK Raharja.

[8] Oktariawan, M. Sugiyanto, and J. Fema, "Pembuatan Sistem Otomasi Dispenser Menggunakan Mikrokontroler Arduino Mega 2560," FEMA, vol. 1, no. April, pp. 1824, 2013. [20] R. Hartono and A. Purnomo, "Wireless Network 802.11," D3 TI FMIPA UNS, vol. 2011, no. UNS, pp. 1-23,2011.

[9] Susanti, Mitta Sisilia. 2005. Aplikasi Berlangganan Koran Menggunakan Layanan SMS di Mitra Bisnis-Group Pikiran Rakyat. Bandung : STTTelkom.rumah berbasis website. tanjungpura: JEPIN.vol.1, no.2

[10] Sadewa,L.Harry.Herry sujandi rudi dwi yoto,2015.Implemetasi Mikrokontroler pada kontrol peralatan listrik dan monitoring

[11] Suharta. 2005, Aplikasi Mikrokontroler sebagai Pengendali Peralatan Elektronik. Jakarta : PT Elek Media Komputindo Kelompok Gramedia

[12] Bagye, W. (2018). Implementasi Jalur Komunikasi Global System Mobile (GSM) Untuk Kontrol Robot Jarak Jauh Berbasis Mikrikontroller Atmel89S52. Jurnal Informatika dan Rekayasa Elektronik, 1(1), 1-6.

[13] Zakaria, Teddy markus. Widiadhi, Josef. 2006."Aplikasi SMS untuk Berbagai Keperluan". Informatika. Bandung.

[14] https://datasheet.octopart.com/A000066Arduino-datasheet-38879526.pdf (diakses pada 05 November 2018).

[15] https://www.espruino.com/datasheets/SIM 900_AT.pdf. diakses pada 05 November 2018).

[16] https://components101.com/sites/default/ files/component_datasheet/HC\%20SR501\% 20PIR\%20Sensor\%20Datasheet.pdf. (diakses pada 05 November 2018).

[17] http://henrysbench.capnfatz.com/wpcontent/ uploads/2015/05/Songle-SRDRelay-Datasheet.pdf. (diakses pada 05 November 2018). 